\title{
LaGuardia in Congress
}




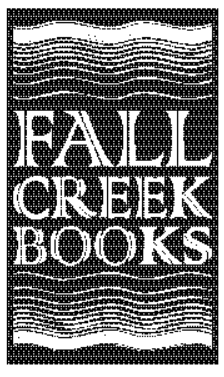

Fall Creek Books is an imprint of Cornell University Press dedicated to making available again classic books that document the history, culture, natural history, and folkways of New York State. Presented in new paperback editions that faithfully reproduce the contents of the original editions, Fall Creek Books titles will appeal to all readers interested in New York and the state's rich past. For a complete listing of titles published under the Fall Creek Books imprint, please visit www.cornellpress.cornell.edu. 


\section{LaGuardia IN CONGRES

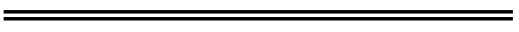 \\ Howard Zinn}

Fa LL Cr e e k B oo k S AN IMPRINT OF

Cor Ne LL UNiv e r Sit Y Pr e SS ITHACA AND LONDON 
Copyright (C) 1958 by Howard Zinn

all rights reserved. except for brief quotations in a review , this book, or parts thereof, must not be reproduced in any form without permission in writing from the publisher.

For information, address Cornell University Press,

Sage House, 512 east State Street, ithaca, New York 14850.

First published by Cornell University Press, 1959

First printing, Fall Creek Books, 2010

Printed in the United States of america 
To Myla and Jeff 
